\title{
The contribution of József Tóth to modernization of Hungarian hydrogeology
}

\author{
Judit Mádl-Szőnyi \\ Department of General and Applied Geology \\ Eötvös Loránd University, Budapest
}

\begin{abstract}
The paper describes the influence of József Tóth and his groundwater flow theory on the evolution of paradigms in Hungarian hydrogeology. The artesian mechanism has been the basic framework for hydrogeologists for the last two centuries. The evolution from the artesian paradigm to basin hydraulics took place in four stages in Hungary. The first stage was represented by the activity of Szebényi (1955), Urbancsek (1963) and Rónai (1963). Their studies were limited to shallow depths, recognizing the correlation between downward and upward flow with high and low topography, but did not produce a model for the observed pattern. In the second stage Erdélyi (1976) enhanced the gravity-driven flow-pattern for shallow depths but avoided the question of deep overpressures. In the third stage Tóth and Almási (2001) concluded that the groundwater flow pattern is made up of an overpressured regime driven by tectonic compression and a topography-driven meteoric regime above it. In the fourth stage Tóth and Almási (2001)'s conclusions were confirmed by studies for the Danube-Tisza Interfluve (DTI) by Mádl-Szőnyi and Tóth (2009). It was found that the gravity-flow systems are perched on ubiquitously ascending waters and that vertical flow occurs through conductive faults and between rock grains.
\end{abstract}

Key words: artesian paradigm, hydraulic continuity, modern hydrogeology, groundwater flow theory, Pannonian Basin

\section{Introduction}

József Tóth was only thirty years old when he published his famous papers on a theoretic analysis of groundwater flow in small drainage basins (Tóth 1962, 1963). He received the first O. E. Meinzer Award of the Geological Society of America for this work in 1965 (Fig. 1). More than forty years later he was

Address: J. Mádl-Szőnyi: H-1117 Budapest, Pázmány P. sétány 1/C, Hungary e-mail: szjudit@ludens.elte.hu

Received: September 1, 2008; accepted: October 27, 2008 


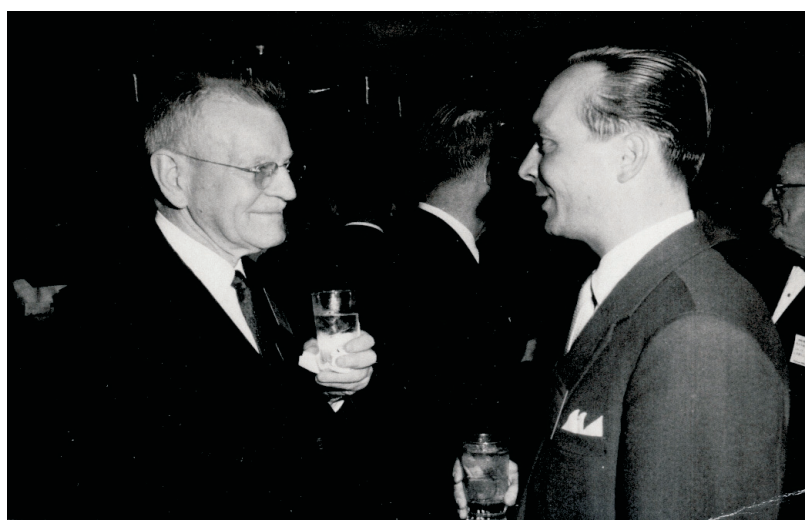

Fig. 1

King Hubbert and József Tóth at the reception following the Meinzer Award Ceremony (Official photo of the GSA, Kansas City, Missouri, November 6, 1965)

interviewed as an Eminent Person in Hydrogeology at the Geological Society of America Conference in Denver in October 2007 (Simmons and Renard 2008). In this GSA meeting a section titled "Regional Groundwater Flow I: In Honor of József Tóth" was organized as well.

Between these two occasions, in the course of Tóth's globally well-known scientific career, he was in active communication with Hungarian hydrogeologists. Nevertheless the details of his activities, and his contribution to the change of paradigms in Hungarian hydrogeology, have not yet been published. The aim of this paper is to describe the influence of Tóth and his regional groundwater flow theory on the evolution of paradigms in Hungarian hydrogeology.

\section{The artesian and the basin hydraulic paradigm in the overall evolution of hydrogeology}

The artesian mechanism was the basic framework for hydrogeologists in their thinking during the 19th century. Some remnants of the artesian approach still exist in Hungary. The word "artesian" came from the town of Artois in France. In the artesian way of thinking, there are aquifers between aquicludes. Infiltration occurs by means of outcropping aquifers. The water level in an artesian well, based on the principle of communicating vessels, rises as high as the water level at the basset outcrops (Fig. 2). In this approach the shallowest aquifer above an aquiclude is regarded to have been recharged directly by precipitation.

The artesian mechanism has become obsolete worldwide since the 1960s, and the natural and engineering science branches of hydrogeology began to converge toward each other (Figs 3 and 4).

The main reason for this was the recognition of basin-scale regional hydraulic continuity (Tóth 1995) among both engineers and scientists. This means leakage through strata that were earlier assumed to be impermeable. In hydrologic engineering the revealing of leakage through multiple aquifer systems is connected to Neuman and Witherspoon $(1969,1972)$. 
Fig. 2

Sketch of the artesian mechanism

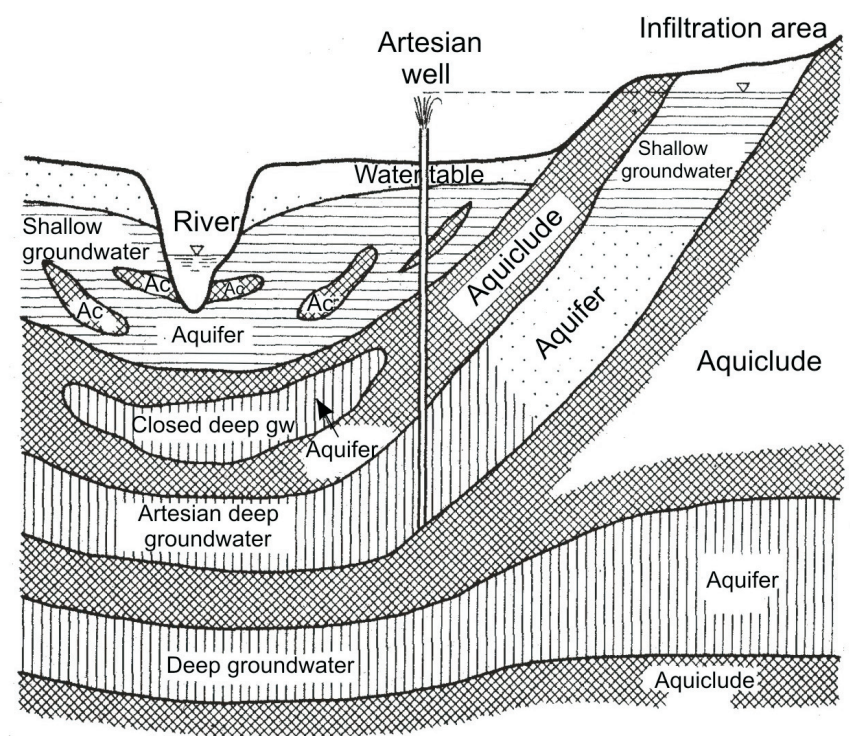

In the natural sciences branch of hydrogeology the theoretical benchmarks of development were: Tóth (1963, 1978), Tóth and Millar (1983), Freeze and Witherspoon (1966, 1967) and Zijl and Nawalany (1993). The empirical approach was used by Walton (1960), Kolesov (1965), Mifflin (1968), Margat (1969), Erdélyi (1976) and Ortega and Farvolden (1989) (Fig. 4).

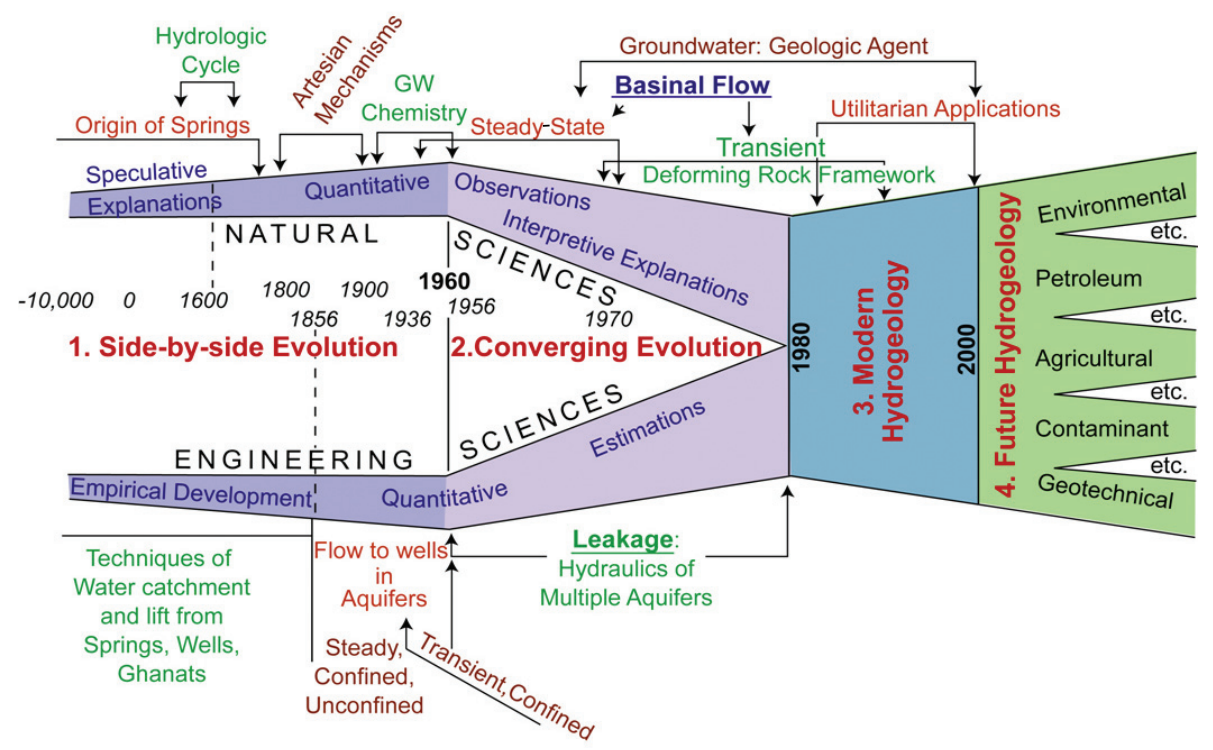

Fig. 3

Flowchart of the evolution of hydrogeology (Tóth 2004) 
192 J. Mádl-Szônyi

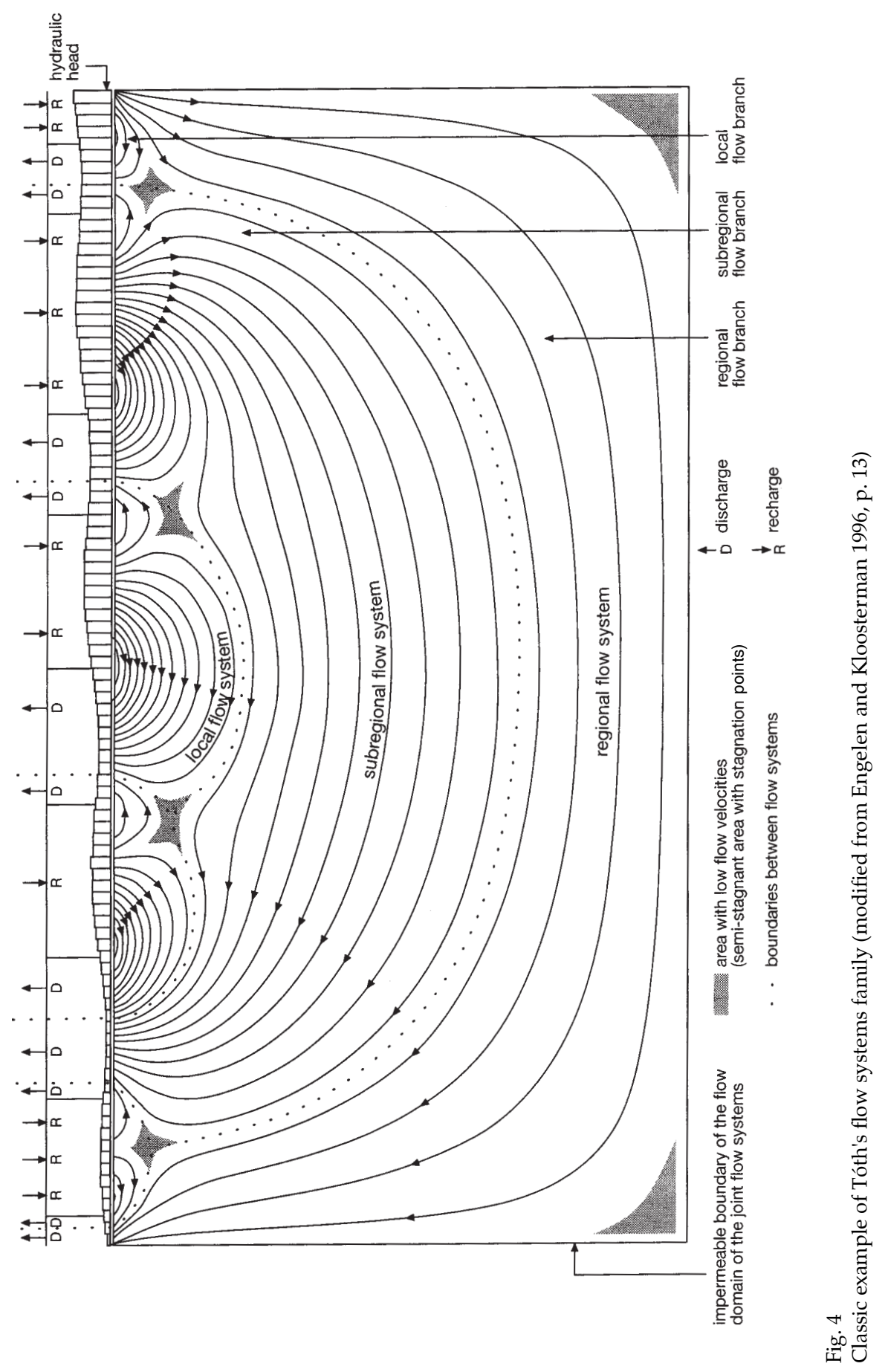

Central European Geology 51, 2008 
The convergence of the two previously independent branches of hydrogeology resulted in the development of basin-scale thinking in hydrogeology, the so-called "modern hydrogeology". In this approach the great sedimentary basins are composed of multiple, regionally extensive aquifer systems (Tóth 1995). The decisive features of modern hydrogeology are basinal flow, the basinal scale of the groundwater-related natural phenomena (Tóth 1980, 1999) (Fig. 5), the transiently deforming rock framework, and the usage of appropriate space and time scales in problem-solving. In modern hydrogeology, hydrogeologic ideas and practical solutions are scale-dependent (Tóth 2000a). At present modern hydrogeology is undergoing differentiation internationally (Deming 2002).

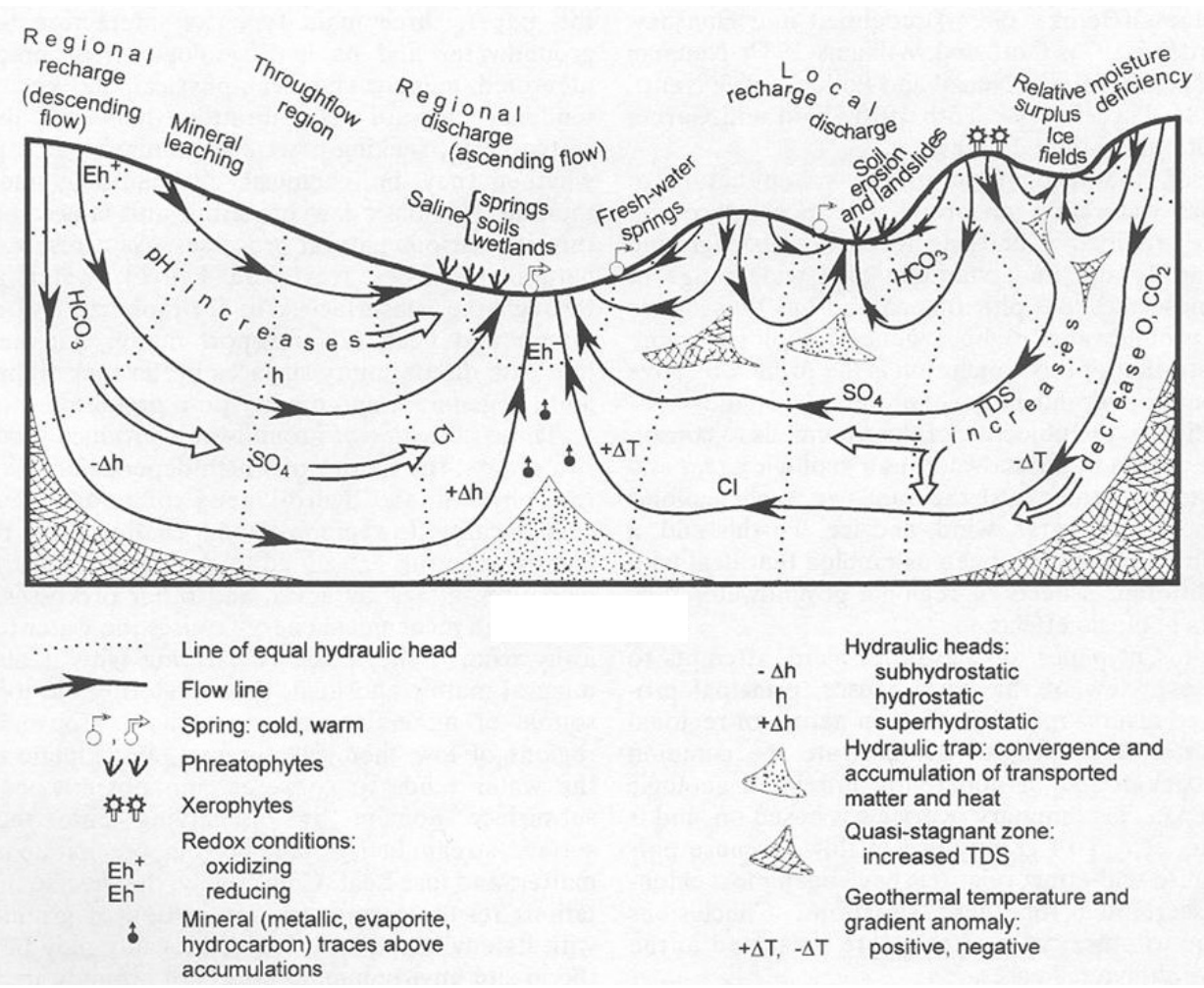

Fig. 5

Gravity flow of groundwater in an unconfined drainage basin: effects and manifestations (Tóth 1999, Fig. 1, modified from Tóth 1980, Fig. 10) 


\section{The main steps from the artesian mechanisms to modern hydrogeology in Hungary}

In the following the development of the modern hydrogeologic principle will be illustrated, related to Tóth himself, within a Hungarian context.

\section{The mediating contribution of József Tóth}

The very first papers raising the issue of vertical motion of groundwater, i.e. leakage, were published among others by Szebényi (1955), Schmidt Eligius (1962), Urbancsek (1963) and Rónai (1963). These studies are illustrated by a crosssection of Rónai (1963) (Fig. 6). The section displays the topography contours, the pressure heads, the depth of water level and temperature data, as well as the direction of vertical flux; the correlation between high and low topography, the vertical flux component and temperature can be recognized from it.

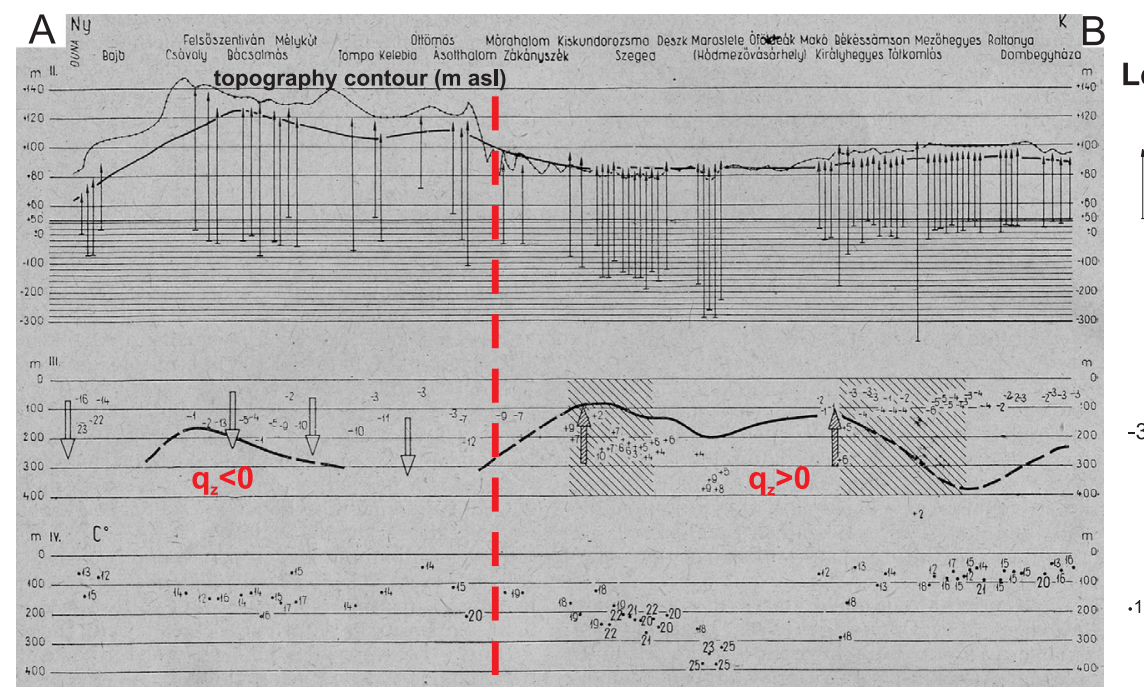

Fig. 6

Quaternary strata of the Great Hungarian Plain (modified from Rónai 1963, Fig. 5). 1. Pressure heads from $\mathrm{P}(\mathrm{m})$ : represented by arrows; 2 . Depth of water: $+/-(\mathrm{m})$; 3 . temperature of water $\left({ }^{\circ} \mathrm{C}\right)$

These studies were limited to shallow depths (max. 400 m; Fig. 6), recognized the correlation of downward and upward flow with high and low topography, but did not produce an explanatory framework for the observed pattern. Therefore, the artesian paradigm was still maintained.

Tóth's activity in Hungarian hydrogeology began with his letter to Rónai on 12 December 1963. This document confirms that, first, based on Rónai's study cited above (Rónai 1963) Tóth recognized the similarity between the Pannonian Basin and the Canadian Prairie, and second, that Tóth found that his general theories 
were valid for the Great Hungarian Plain as well. This exchange of letters was the beginning of a lifelong correspondence (Fig. 7).

Fig. 7

Portraits of a) András Rónai and b) Mihály Erdélyi (photos provided by P. Scharek; photographer unknown)

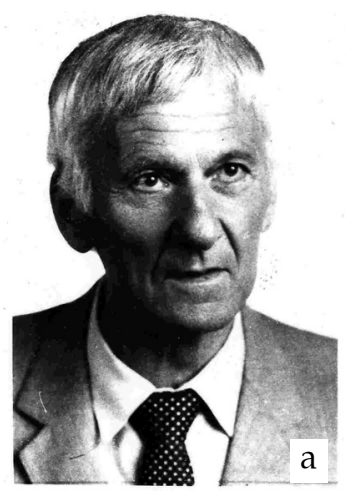

Continuity was provided by Erdélyi (Fig. 7), who wrote to Tóth on 21 June 1971 and sent him his manuscript on the hydrodynamics of the Pannonian Basin (Erdélyi 1976). Erdélyi summarized his results in a specific section (Fig. 8) in which he used a logarithmic vertical scale to enhance the details of flow-pattern geometry at shallow depths, while avoiding the questions of distribution and the

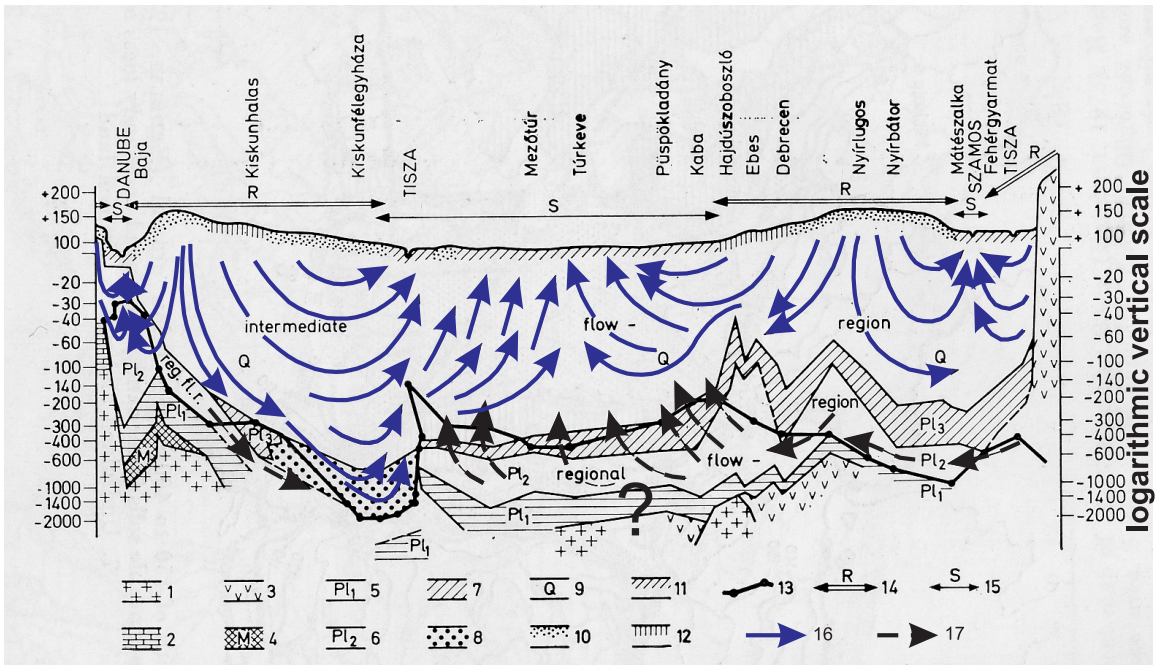

Fig. 8

Schematic flow-pattern of the Great Hungarian Plain (modified from Erdélyi 1976, Fig. 3. p. 292). 1. crystalline basement; 2 . Mesozoic limestone; 3 . Miocene volcanics; 4 . Miocene deposits; 5 . Lower Pannonian (Pliocene), impermeable, poorly permeable; 6. Upper Pannonian (Pliocene) permeable, poorly permeable; 7. Upper Pliocene, poorly permeable; 8 . Upper Pliocene, highly permeable; 9. Quaternary in general; 10 . dune sand, loessy sand; 11 . silt, clay, soda soils; 12 . loess, sandy loess; 13. fresh-water and brine interface; 14. recharge; 15. discharge area; 16. flow direction; 17. supposed flow direction 
origins of deep overpressure. He wrote to Tóth in the above-mentioned letter: "In the knowledge of your papers, which I greatly respect, I finished my study on the Hydrodynamics of the Pannonian Basin [...] I feel that, based on a huge amount of field data, I have succeeded in verifying and further developing your flowsystem concept for a large basin." Based on the preceding it can be concluded that the Great Hungarian Plain provides empirical evidence for Tóth's flow-system model. Gravitational driving force was recognized for the upper parts of the basin. However, the cause of the deep overpressures remained unknown. At this phase a new dynamic paradigm was born in Hungarian hydrogeology.

\section{Activity of József Tóth in Pannonian Basin-related research}

Tóth and his PhD student of Hungarian origin, Istvan Almási, published their study (Tóth and Almási 2001), which was supported by the Hungarian Oil Company MOL, in Geofluids in 2001. This research study was based on over 16,000 fluid-potential data from between a few to over $3000 \mathrm{~m}$ of depth. The authors found two principal driving forces for fluid flow in the Pannonian Basin. One of them is due to elevation differences of the topographic relief, and the other is a consequence of tectonic compression in the deep part of the basin (Fig. 9). The Great Plain is under the influence of tectonic compression, which is confirmed by intraplate crustal velocity data for the Pannonian Basin (Grenerczy et al. 2001, in Tóth and Almási 2001).

The overpressured regime is confined, whereas the meteoric regime is unconfined. It was found that the nature and the geometry of the transition between the two regimes are controlled by sedimentary windows and conductive faults. This paradigm provided data control and led to a new conceptual model for the flow system of the Great Hungarian Plain, which forms part of the Pannonian Basin.

The Pannonian Basin has been considered by Tóth as a special hydrogeologic research laboratory where the processes and manifestations of groundwater flow can be studied. A research proposal entitled "Pannonian Basin Hydrogeologic Research Project" (PBHRP) (Tóth 2000b) was proposed by József Tóth and his Hungarian colleagues Béla Angelus, Zsófia Bakacsi, Zsolt Molnár, János Szanyi, Judit Mádl-Szőnyi, Péter Szúcs and Irén Varsányi in 2000.

"The purpose of the proposed program (PBHRP) is to set the stage for the development of a comprehensive and coherent understanding of the hydrogeologic conditions in the Great Plain and Little Plain portions of the Pannonian Basin in Hungary. The central objective of the study is, therefore, to characterize and interpret the regional distribution of the formation waters' fluid potential in the two Plains... Such basin-scale characterization of the fluid potential field allows inferences to be made, albeit only as a first approximation, regarding the origin and nature of fluid-driving forces, regional patterns of subsurface water-flow, principal controls on flow geometry, type and nature of 


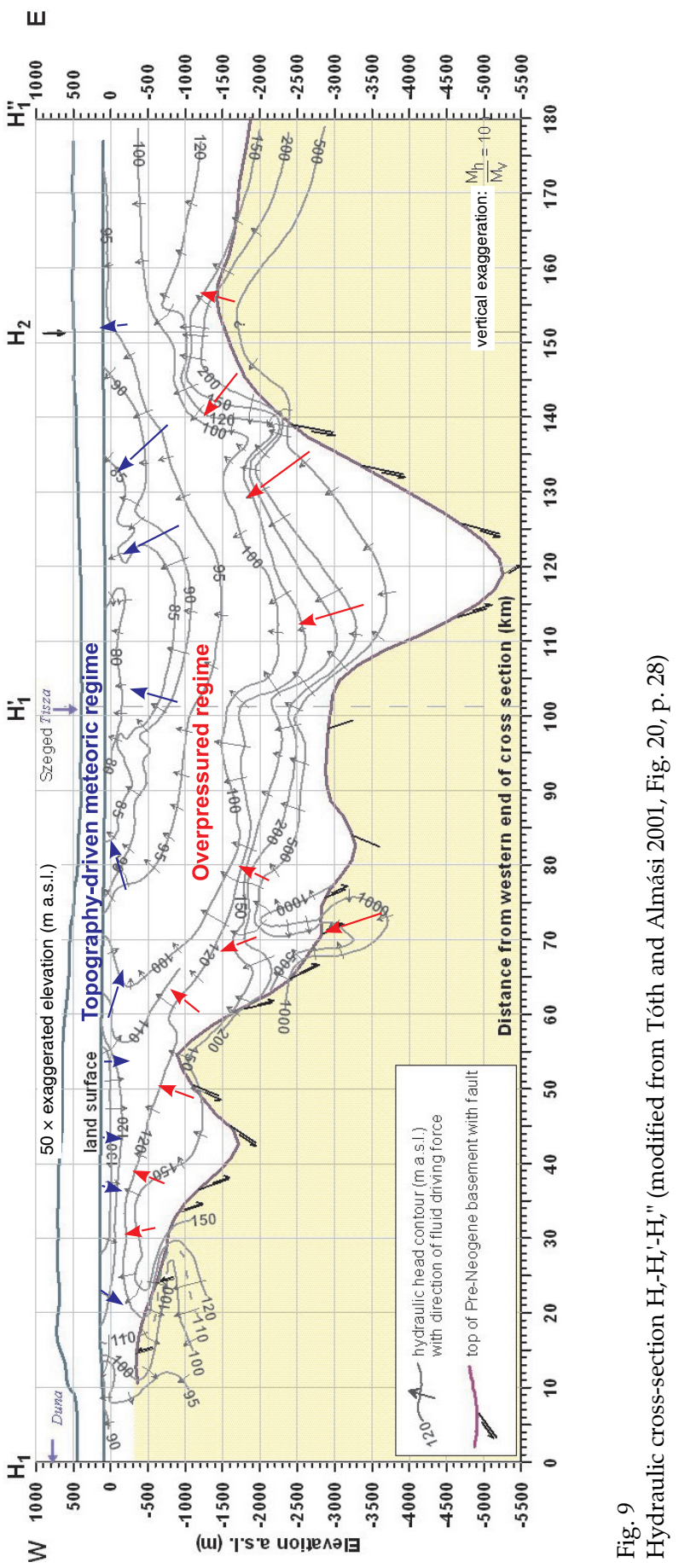


potentiometric anomalies caused by structural or sedimentological dicontinuities, ... and a number of groundwater-related natural processes and phenomena such as chemical composition of groundwater, vegetative cover, soil salinization, and so on." (Part I: General Consideration in Tóth 2000b p. 3). Five basin-scale and seven gravity-flow projects were outlined for the two Plains (i.e. Great Hungarian Plain and the Little Plain, respectively).

A set of studies was initiated at Eötvös Loránd University (ELTE), beginning in the new millennium and within the framework of the PBHRP, by the contribution of József Tóth. The goals of these studies were to refine the results of the previous paradigm outlined by Tóth and Almási (2001) and to answer questions concerning the origin of salts occurring at surface, and about the controls on the distribution of the ecologically different regions for the marginal part of the Pannonian Basin, i.e. the Danube-Tisza Interfluve.

Based on these studies Tóth and Almási's conclusions (2001) could be confirmed and further developed (Mádl-Szőnyi and Tóth 2009). It could be concluded that the gravity-flow systems are perched on ubiquitously ascending waters in the Danube-Tisza Interfluve; vertical flow occurs through conductive faults and between rock grains. These faults could be identified by seismic section interpretation. It was realized that beneath the highlands the vertical flow is downward for the gravity regime and upward for the overpressured regime. Beneath the depressions, on the other hand, the vertical flow points uniformly upward for both regimes. It was also recognized that the salts originate partly from the basement and partly from the basin sediments, and are distributed by groundwater discharge controlled by the interplay between the gravitational and overpressured systems.

From the generalized results of these studies, a hydrogeologic scheme, the socalled Type Section, was deduced for the Danube-Tisza Interfluve (Mádl-Szőnyi and Tóth 2009) (Fig. 10).

Tóth's research in Hungary was based on the PBHRP project proposal (Tóth $2000 \mathrm{~b})$. This proposal provides a framework to conduct basin hydraulic research in the Pannonian Basin, not only for the present but for the future as well.

\section{Summary}

The artesian mechanism was the basic framework for hydrogeologists until the second half of the 20th century. The evolution from the artesian paradigm to basin hydraulics occurred in four stages in Hungary. József Tóth played specific role in all of these stages. In the first two phases he helped in passive way, by means of correspondence with Hungarian hydrogeologists. The studies in the first phase were limited to shallow depths, recognizing the correlation between flow direction and topography, but did not produce a model for the observations made (Szebényi 1955; Urbancsek 1963; Rónai 1963 etc.). In the second stage Erdélyi (1972) enhanced the gravity-driven flow-pattern for shallow depths but avoided the question of origin and type of deep overpressures. 


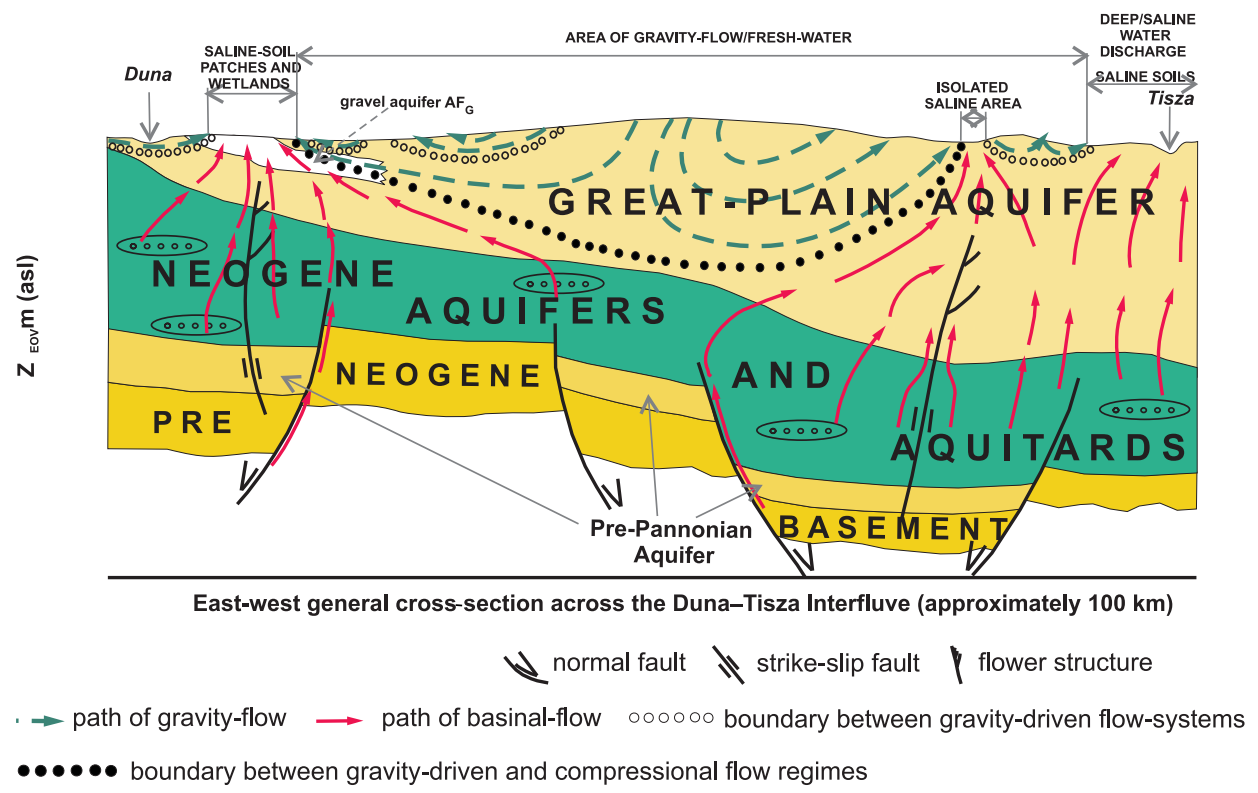

Fig. 10

The Danube-Tisza Interfluve Hydrogeologic Type Section, Hungary (Mádl-Szőnyi and Tóth 2009)

From the 1990s on József Tóth carried out research work in Hungary. Thus the conclusions of the third evolutional stage due to Tóth and Almási's (2001) research were that the groundwater flow pattern comprises an overpressured regime driven by tectonic compression as well as a topography-driven meteoric regime above it. In the fourth stage Tóth and Almási (2001)'s conclusions were confirmed by studies for the Danube-Tisza Interfluve (DTI) by Mádl-Szónyi and Tóth (2009). It was found that the gravity-flow systems are perched on ubiquitously ascending waters and that vertical flow occurs through conductive faults and between rock grains.

\section{Acknowledgements}

The author acknowledges Professor J. Tóth for his parental friendship, for all the long hours spent talking about hydrogeology and for all his efforts to show the author, as well as many students, a special outlook and way of thinking. He also granted permission to inspect his earlier correspondence with Hungarian hydrogeologists. The research on the Danube-Tisza Interfluve was supported by the Hungarian OTKA grant No. T 047159 to J. Mádl-Szônyi. For technical assistance many thanks are due to B. Czauner. 


\section{References}

Deming, D. 2002: Introduction to Hydrogeology. - McGraw-Hill Higher Education, 468 p.

Engelen, G.B., F.H. Kloosterman 1996: Hydrological Systems Analysis Methods and Applications. Water Science and Technology Library, 20, Kluwer Academic Publishers, Dordrecht, Boston, London.

Erdélyi, M. 1976: Outlines of the hydrodynamics and hydrochemistry of the Pannonian Basin. Acta Geologica Academiae Scientiarum Hungaricae, 20/3-4, pp. 287-309.

Freeze, R.A., P.A. Witherspoon 1966: Theoretical analysis of regional groundwater flow: 1. Analytical and numerical" solutions to the mathematical model. - Water Resources Research, 2/4, pp. 641-656.

Freeze, R.A., P.A. Witherspoon 1967: Theoretical analysis of regional groundwater flow. 2. Effect of water table configuration and subsurface permeability variation. - Water Resources Research, 3/2, pp. 623-634.

Grenerczy, Gy., A. Kenyeres, I. Fejes 2000: Present crustal movement and strain distribution in Central Europe inferred from GPS measurements. - Journal of Geophysical Research, 105, pp. 21.835-21.846.

Kolesov, G.D. 1965: On the question of artesian feeding of rivers. - Soviet Hydrology, Selected Papers, 3, pp. 195-203. (In Russian.)

Margat, J. 1969: Remarques sur la signification des surfaces piezometriques des nappes captives. Chronique d'Hydrogeologie de BRGM, Paris 12, pp. 13-17. (In French.)

Mádl-Szőnyi, J., J. Tóth 2009: A hydrogeological type section for the Duna-Tisza Interfluve, Hungary. - Hydrogeology Journal. DOI: 10.1007/s10040-008-0421-z

Mifflin, M.D. 1968: Delineation of ground-water flow systems in Nevada. - Publ. No. 4. Technical Report Series H-W, Center for Water Resources Research, Desert Research Institute, University of Nevada System, Reno.

Neuman, S., P. Witherspoon 1969: Applicability of current theories of flow in leaky aquifers. - Water Resources Research, 5/4, pp. 817-829.

Neuman, S., P. Witherspoon 1972: Field determination of hydraulic properties of leaky multiple aquifer systems. - Water Resources Research, 8, pp. 1284-1298.

Ortega, G.A., R.N. Farvolden 1989: Computer analysis of regional groundwater flow and boundary conditions in the basin of Mexico. - Journal of Hydrology, 110, pp. 271-294.

Rónai, A. 1963: Az Alföld negyedkori rétegeinek vízföldtani vizsgálata (Hydrogeological evaluation of the Quaternary strata of the Great Hungarian Plain). - Hidrológiai Közlöny, 43/5, pp. 378-391. (In Hungarian.)

Schmidt Eligius, R. 1962: Vázlatok és tanulmányok Magyarország vízföldtani atlaszához (Sketches and studies to the Hydrogeological Atlas of Hungary). - Budapest, 1962. Múszaki Könyvkiadó. (In Hungarian.)

Simmons, C.T., P. Renard 2008: Editors' Message: the Hydrogeologist Time Capsule archival video recordings of influential hydrogeologists. - Hydrogeology Journal, 16, pp. 1-3.

Szebényi, L. 1955: Artézi vizek függőleges irányú mozgásáról (On the vertical motion of artesian waters). - Hidrológiai Közlöny, 35, pp. 437-439. (In Hungarian.)

Tóth, J. 1962: A theory of groundwater motion in small drainage basins in central Alberta, Canada. Journal of Geophysical Research, 67/11, pp. 4375-4387.

Tóth, J. 1963: A theoretical analysis of groundwater flow in small drainage basins. - Journal of Geophysical Research, 68/16, pp. 4795-4812.

Tóth, J. 1978: Gravity-induced cross-formational flow of formation fluids, Red Earth Region, Alberta, Canada: analysis, patterns and evolution. - Water Resources Research, 14/5, pp. 805-843.

Tóth, J. 1980: Cross-formational gravity-flow of groundwater: A mechanism of the transport and accumulation of petroleum (the generalized hydraulic theory of petroleum migration). - In: Roberts III W.H., R.J. Cordell (Eds): Problems of petroleum migration. AAPG Studies in Geology 10, pp. 121-167. 
Tóth, J. 1995: Hydraulic continuity in large sedimentary basins. - Hydrogeology Journal, 3, pp. 4-16.

Tóth, J. 1999: Groundwater as a geologic agent: An overview of the causes, processes, and manifestations. - Hydrogeology Journal, 7/1, pp. 1-14. Also published in Spanish translation: Tóth, J. (2000) Las aguas subterraneas como agente geologico: causas, procesos y manifestaciones. Boletin Geologico y Minero 111/4, pp. 9-26.

Tóth, J. 2000a: The key to improvements in aquifer protection: Analytical hydrogeology. - Acta Geologica Hungarica, 43/2, pp. 145-155.

Tóth, J. 2000b: Pannonian Basin Hydrogeological Research Program (PBHRP) - Proposal and List of Suggested Component Projects, 1 December 2000, Edmonton, Alberta/Canada 34

Tóth, J. 2004: Gravitational systems of groundwater flow; principles, evaluation, and utilization. Short Course Vol. (C-3), XXXIII-IAH Congress, Groundwater flow understanding from local to regional scales $134 \mathrm{p}$.

Tóth, J., I. Almási 2001: Interpretation of observed fluid potential patterns in a deep sedimentary basin under tectonic compression: Hungarian Great Plain, Pannonian Basin. - Geofluids, 1/1, pp. $11-36$.

Tóth, J., R.F. Millar 1983: Possible effects of erosional changes of the topographic relief on pore pressures at depth. - Water Resources Research, 19/6, pp. 1585-1597.

Urbancsek, J. 1963: A földtani felépítés és rétegvíznyomás közötti összefüggés az Alföldön (Relationship between the geological framework and the formation water pressure in the Great Hungarian Plain). - Hidrológiai Közlöny, 3, pp. 205-218. (In Hungarian.)

Walton, W.C. 1960: Leaky artesian aquifer conditions in Illinois. - Illinois Water Survey Report of Investigations, 39, pp. 1-27.

Zijl, W., M. Nawalany 1993: Natural groundwater flow. - Lewis Publishers, Boca Raton, Florida, U.S.A.

Correspondence

Tóth's letter to Rónai (12 December 1963) concerning Rónai's (1963) paper and Rónai's reply to Tóth (28 December 1963)

Letter from Erdélyi to Tóth (21 June 1971) 